\title{
EMPLOYER BRANDING AS RECRUITMENT AND RETENTION TOOL FOR THE UNIVERSITIES
}

\author{
Asta Radzevičiené ${ }^{1}$, \& Aleksandra Sokolova ${ }^{2}$ \\ Vilnius Gediminas Technical University (Lithuania) \\ ${ }^{1}$ Department of Management, ${ }^{2}$ International Relations Office
}

\begin{abstract}
Increasing competition for the best employees calls for the search of the comprehensive strategies to attract and retain potential and current employees. Despite different business and academic work contexts, number of employer branding activities applied by business companies might be transferred to universities. Literature review shows positive associations between employer branding activities to attracting and retaining employees at various types of organisations. However, the implementation of various employer branding activities remains challenging for organisations and is insufficiently explored in the context of at higher education human resource management. The authors of this paper reflect upon the main aspects of the employer branding strategy, opportunities available and suggest insights into its practical implementation at universities.
\end{abstract}

Keywords: Employer branding, recruitment, retention, employer value proposition.

\section{Introduction}

Nowadays universities are increasingly competing on national and global markets not only for local and international students but also for academics management professionals. This tendency is paralleled by uneven and decreasing public funding for universities, increasing competition for best talents with other universities and business companies. Universities are driven by the need to find comprehensive strategies for effective human resource management (HRM) - recruiting and retaining the best employees, academic as well as administrative staff. Moreover, universities have to update their traditional human resource (HR) practices in order to be attractive enough for the young generation in academia, to be visible as potential employers among other players in the labour market. Employer branding (EB) is one of the HR instruments that proves to be effective with business companies and can be potentially applied at universities in spite of the increasingly complex academic contexts.

Ambler and Barrow (1996) defined employer brand as "package of benefits" provided by employment and identified with the employing organization functional benefits (e.g. training, career development, skills and other job related activities for development), economic benefits (e.g. reward and remuneration) and psychological benefits (e.g. identity, recognition and belonging). Employer branding shall be therefore considered as the blend of attraction, engagement and retention initiatives with company's positioning, attractiveness, and visibility as an employer on the other hand. From a job-market perspective, employer branding has been suggested as an effective way to position the organisation in highly competitive labour markets. Current trends in public pressure for the research and education quality, and performance based government funding intensifies the competition among higher education institutions (HEIs). As a result, they seek for innovative solutions to cope with emerging challenges in attracting and retaining talents, increasingly adopt a more business-like stance and utilise professional marketing practices (Veloutsou et al., 2015). In spite of the differences in business and academic work contexts, their organisational cultures, management strategies and funding opportunities employer branding strategy as whole or its distinct solutions could be successfully applied at universities.

A number of academic literature and research exploring the associations between development of employer brand in companies and performance (e.g. increasing employers' engagement and productivity and reducing turnover) has been published in past decades (Backhouse and Tikoo, 2004; Gilani and Cunningham, 2017; Lievens, F., Slaughter, J., 2016; Theurer et al., 2016). Recently more research dedicated to different aspects of employer branding at HEIs emerged (Bakanauskiene et al., 2011; Brosi and Welpe, 2014; Erasmus et al., 2015; Hemsley-Brown et al., 2016, Hamidizadeh, Ali \& Fadardi, Mansoureh. 2019). Although both potential and current employees are discussed in the most conceptualisations of employer branding (e.g. Lane, 2016), the majority of empirical research focuses on recruitment in particular. Similarly, the majority of research on EB at HEI explores the aspects of the branding activities aimed at attracting and retention of academics as a core HR group. EB focusing on administrative staff remains relatively under-researched. 


\section{Conceptualisation of employer branding}

Since employer brand concept introduction by Ambler and Barrow (1996), this area received attention of the researches as well as HRM professionals. Further on the process of employer branding has been defined as an approach to recruitment and retention that "involves internally and externally promoting a clear view of what makes a firm different and desirable as an employer" (Lievens, 2007, p. 51). The concept reflects a broad spectrum of ideas related to the way in which potential and current employees interact with a company's brand and, in particular, the company's brand image as an employer (Ambler and Barrow, 1996; Ewing et al, 2002; Backhaus and Tikoo, 2004). Historically the branding concept has been developed in marketing area, but over time has become one of the important strategies of human resource management, especially in recruitment (Cable and Turban, 2001). Following the Sparrow and Ottaye (2015) creation of employer brand could be seen as a three-step process:

1. Development of the employee value proposition (EVP) based on information about organisation's culture, management style, remuneration, training and career development opportunities, work-life balance, qualities of current employees, current employee image and impressions of product or service quality;

2. External marketing of EVP to targeted potential employees designed to attract applicants as well as support, align and enhance corporate brand;

3. Internal marketing aimed at carrying the "brand promise" made to applicants, embedding it into the organisation culture and ensuring commitment by employees to the values and goals encoded in the brand.

EVP is the core element of the employer brand (i.e. brand for which people work) and should be differentiated from the unique sales proposition (USP) that lies at the heart of product or service brand (i.e. brand that people buy). In the first case, the experience of candidate or employee matters and in latter case the experience of consumer/client matters the most. In spite of the differences of the two, both are linked via corporate brand concept, which represents the manifestation of values, vision and mission of the organisation. Relationship between the abovementioned concepts is represented in Figure 1.

Figure 1. The relationship between corporate brand, product brand and employer brand. Source: Mokina (2014).

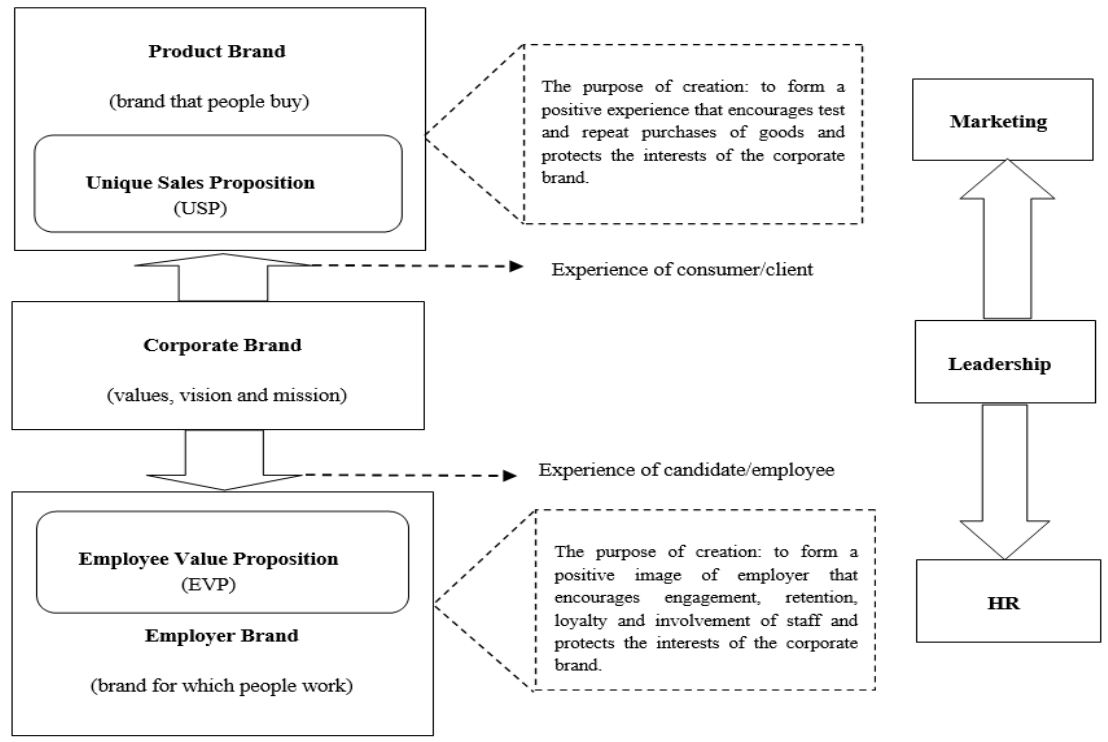

The research and discussions over the EB is still evolving at the intersection of marketing, human resources management and organisational psychology. Consequently the academic literature and research approaches this phenomenon from different theoretical perspectives that results in lack of common understanding among academics and practitioners on the definition, underlying theoretical assumptions (Moroko and Uncles, 2005; Theurer et al., 2016) and deliverables of EB.

Since the initial concept of EVP expressed in terms of functional, economic and psychological benefits emerged, various authors have further explored and expanded the list of values that seem to predict favourable employee attitudes. According to Berthon et. al., (2005) and Uppal et. al. (2018) the following EB value attributes are generalised.

Economic value - the degree to which the employer provides above average rewards, compensation and benefits, job security and promotion. Researchers and HR practitioners quite unanimously agree on inevitable presence of this element in majority of motivation systems. 
Reputation value - the degree to which the employer meets employees' expectations and perceptions, supports fair business relationships and holds unique intellectual property assets. According to the report by Thomson Reuters and Interbrand (2004) business's most valuable asset is its good name, its brand and reputation. University reputation is associated with international rankings (e.g. QS World University Rankings, Miltirank, Times Higher Education), especially having in mind that they incorporate the academic and employer reputation metrics. Working for the highly ranked university creates the added value for the individual $\mathrm{CV}$ of academic which is highly relevant for international mobility and employment pursuit.

Development value - the degree to which the employer provides recognition, self-worth, confidence, career-enhancing experience that serves for the future employability. Employer branding global trends study report (2014) refers to the career development as one of the most important attributes in attracting new talent to a company.

Working environment value - the degree to which the environment and conditions at work support the employee needs and expectations. One of the important aspects of this value of growing importance is related to the kind of balance between work and life could be arranged. Together with compensation $(47,1 \%)$, work-life balance $(41 \%)$ constitutes one of the top attributes influencing employer selection according to the Global Talent Monitor (2020). This particular attribute refers to the value creation for employee in terms of flexible work schedule, family holidays, consultation, childcare services as well as other means that could be offered by the employer in order to make sure better work-life balance.

\subsection{University brand management}

Ideas about employer branding goes beyond the initial focus on more effective management of recruitment and retention, thus is shaped in broader employer branding strategy characterised by the set of strategic activities. In spite of the spreading of the EB activities at companies in recent decade only $17 \%$ of companies who participated in the 2014 Employer Branding Global Trends Study had a clear employer branding strategy, 35\% had the strategy, but felt the need of further development. "Across regions many companies are still in the early stages of their employer brand strategy" (Minchington, 2014, p. 12). The percentage of universities having the targeted employer branding strategy is expected to be even less. Companies experience certain difficulties with setting the indicators and measuring benefits of EB strategy. However social media participation (11\%), defining EVP's (11\%), talent development strategy $(9 \%)$ and career website development $(9 \%)$ are supposed to be the most effective activities to enhance the employer brand.

Employer branding is an example of how organisations convert their values and culture into EVP that makes them distinctive from other players in the market. This opens up the space for HR to become involved with marketing professionals acknowledging a key role in shaping the corporate brand (Sparrow and Otaye, 2015). It is argued that the head of HR should be seen as the main member of the branding team as it develops the policy that influences the creation of brand, in particular recruitment programs, adaptation of new employees, training and rewarding (De Chernatony, 2006). However, the EB strategy ownership in companies evolves with the time as well. Needless to say, that this is true to the business companies and does not take into consideration all peculiarities and realities of the university HRM policy and practices. The role of the university as an employer is rarely discussed (Matongolo et al., 2018, Hamidizadeh et al. 2019), much greater attention of the researchers is given to the university brand that is build and developed in order to attract potential students and the related topics (Chen, 2019; Maresova et al. 2020).

HR professionals' readiness to adapt and be the part of the more strategic approach is crucial as the process is characterised by complexity, conflict and lack of clarity in terms of how to apply it. Although HR literature argues that HR status has firmly established itself in terms of status and contribution to the organisation effectiveness (Armstrong, 2007), research shows that there is both role conflict and role ambiguity (Mansour et al., 2015). Researches received some evidence that, the role of $\mathrm{HR}$ at HEI has become increasingly strategic, proactive and intended to apply more business-like practices.

As it is shown in the Employer Branding Global Trends Study (2014), the employer brand strategy is increasingly managed by the marketing and communication professionals instead of leaving it in the sole domain of HR departments. It stresses the importance of the holistic approach to EB strategy that would be focused not solely on recruiting talents, but also on employee engagement and retention. This approach requires effective coordination and input from different units of the organisation.

\section{Discussions}

There are many EB activities characterised by high impact at relatively low costs that could be applied by universities. Therefore, we are suggesting the following four recommendations for the universities employer branding strategy development: 
1. Discuss the place and scope of the EB in the university strategic plan (e.g. marketing strategy or/and HR strategy). It is advised to focus on 3-5 activities that are related to recruiting and retaining talents (ideally targeted at academic and administrative staff respectively);

2. Define your EVP based on distinctive university assets and most important attributes which target audience is seeking as employment experience;

3. Delegate the responsibility (decide on who will take the EB leadership - PR/Communication department or HR department and how the brand promise and its implementation will be coordinated);

4. Communicate your EVP to targeted audiences (applicants and potential employees, apprentices/trainees, current employees) via selected communication channels (social media, intranet, other) and brand ambassadors (prominent academics, administration representatives, alumni, other).

There is a need for the better clarity on driving motivators of attraction, engagement and retention of current employees and identification of the gaps between the aspirations, expectations of employers and employees about the employment experience.

It is important for universities to create their online presence and look after all key channels to engage with the key audiences. As is shown in Employer branding global trends study report (2014) social media $(76 \%)$ is the main communication channel for promotion of employer brand. Universities must be ready to make sure the presence and communication of the brand via social media channels (e.g. Facebook for corporate communication media, social networking, service and LinkedIn for business and employment-oriented social media service for professional networking, including job posts and job seekers CVs). Building attractive and easy to navigate career page on your university website that include information on benefits of working for the organisation, testimonials of current employees, mentoring programmes for new employees, training opportunities, etc. would greatly contribute to EB.

In the course of the implementation the abovementioned recommendations universities should be aware of the differences that could be associated with the age, gender and current employment status of the target EB groups (Alnıacik and Alnıacik, 2012).

In order to take forward the discussion on university employer brand the complex context and nature of higher education institution shall be taken into consideration where academics constitute the core group of employees, administrative staff has different employment terms and conditions, and there is a special group of employees having a double role. The business model approach to employer branding seems to be potentially easier applicable to administrative staff, however this approach does not bring the holistic solution for university HRM.

\section{Conclusions}

The article has focused on employer branding conceptualisation and research findings that are associated with employer recruitment and retention. Ideas of EB research and implementation at business companies are generalised to provide insights into its practical implication at universities. It was claimed that universities could potentially implement a range of EB activities for recruiting and retaining talents - discussing the place, scope and ownership of EB in university strategic plan, defining and communicating employer value proposition to targeted audiences via selected communication channels. There is a need for differentiated EVP approach to academic and administrative staff based on the analysis of their needs and expectations. However, complex academic contexts should be seriously considered before taking the call for EB action at universities. Implementing the EB activities even at small scale could bring important strategic advantages to the universities HRM and vice versa - maintaining status quo puts universities at risk of poorer results in attracting and retaining the talents.

\section{References}

Alnıacik, E., Alnıacik, U. (2012). Identifying dimensions of attractiveness in employer branding: effect of age, gender, and current employment status. Procedia - Social and Behavioral Sciences, Volume 58, pp. 1336-1343.

Ambler, T., Barrow, S. (1996). The employer brand. Journal of Brand Management, 4, pp. 185-206.

Armstrong, M. (2007). A handbook of employee reward management and practice. London: Kogan Page.

Backhouse, K. B., Tikoo, S. (2004). Employer branding framework. Conceptualizing and researching employer branding. Career Development International, 9, pp. 501-517.

Bakanauskiene, I., Bendaraviciene, R., Kristolaitis, R. and Lydeka, Z. (2011). Discovering an employer branding: identifying dimensions of employer's attractiveness in university. Organizaciju Vadyba: Sisteminiai Tyrimai (Management of Organizations: Systematic Research), No 59, pp. 7-22.

Berthon, P., Ewing, M. and Hah, L.L. (2005). Captivating company: dimensions of attractiveness in employer branding. International Journal of Advertising, 24 (2), pp. 151-72. 
Brosi, P., Welpe, I. M. (2014). Employer branding for universities: what attracts international postdocs? Journal of Business Economics, 85 (7), pp. 817-850.

Cable, D. M., Turban, D.B. (2003). The value of organizational reputation in the recruitment context: a brand-equity perspective. Journal of Applied Social Psychology, 33, pp. 2244-2266.

Chen, C.T. (2019). The mediating effect of brand identity on brand knowledge and the operational development of universities. South African Journal of Business Management, Vol. 50(1).

De Chernatony, L. (2006). From brand vision to brand evaluation. The strategic process of growing and strengthening brands, 2nd edition, Oxford: Elsevier LTD.

Erasmus, B.J., Grobler, A., and van Niekerk, M. (2015). Employee retention in a higher education institution: an organisational development perspective. Progressio, Volume 37, No 2, pp. 32-62.

Ewing, M., Pitt, L. and De Bussy, N. (2002). Employment branding in the knowledge economy. International Journal of Advertising, 21, pp. 3-22.

Gilani, H., Cunningham, L. (2017). Employer branding and its influence on employee retention: A literature review. The Marketing Review, 17(2): 2, pp. 239-256.

Global Talent Monitor. 3Q19: Update on Workforce Activity. Gartner, Inc. 2020. Retrieved April 17, 2020, from: //www.gartner.com/en/human-resources/trends/global-talent-monitor

Hamidizadeh, A., and Fadardi, M. (2019). The brand of a university as an employer. Human Systems Management. 38. 73-86.

Hemsley-Brown, J., Melewar, T.C., and Nguyen, B. (2016). Exploring brand identity, meaning, image, and reputation (BIMIR) in higher education: a special section. Journal of Business Research, 69 (8), pp. 3019-3022.

Lane, P. (2016). Human resources marketing and recruiting: essentials of employer branding. In Zeuch, M. (ed.), Handbook of Human Resources Management. Berlin: Springer, pp. 23-52.

Lievens, F. (2007). Employer branding in the Belgian Army: the importance of instrumental and symbolic beliefs for potential applicants, actual applicants, and military employees. Human Resource Management, 46, pp. 51-69.

Lievens, F., Slaughter, J. (2016). Employer image and employer branding: what we know and what we need to know. Annual Review of Organizational Psychology and Organizational Behavior, Vol. 3, pp. 407-440.

Mansour, H. F., Heath, J., Brannah, M. J. (2015). Exploring the Role of HR Practitioners in Pursuit of Organizational Effectiveness in Higher Education Institutions. Journal of Change Management, Vol. 15, No 3, pp. 210-230.

Maresova, P.; Hruska, J.; Kuca, K. Social Media University Branding. Educ. Sci. 2020, 10, 74.

Matongolo, A., Kasekende, F. and Mafabi, S. (2018). Employer branding and talent retention: perceptions of employees in higher education institutions in Uganda. Industrial and Commercial Training, Vol. 50 No. 5, pp. 217-233.

Minchington B. (2014). Employer branding global trends study report. Employer Brand International. Retrieved January 22, 2020, from: https://www.slideshare.net/brettminch/2014-employerbranding-global-trends-survey-report-by-employer-brand-international

Mokina, S. (2014). Place and role of employer brand in the structure of corporate brand. Economics and Sociology, 7 (2), pp. 136-148.

Moroko, L., Uncles, M. D. (2008). Characteristics of successful employer brands. Journal of Brand Management, 16, pp. 160-175.

Sparrow, P., Otaye, L. (2015). Employer branding. From attraction to a core HR strategy. White Paper 15/01. Centre for Performance-led HR, Lancaster University Management School, Bailrigg, Lancaster, UK.

Spence, M. (1973). Job market signaling. Quarterly Journal of Economics, 87, pp. 355-374.

Theurer, C. P., Tumasjan, A., Welpe, I. M., and Lievens, F. (2016). Employer branding: a brand equity-based literature review ad research agenda. International Journal of Management Reviews, Vol. 00, pp. 1-25.

Uppal, Aakanksha \& Wadhwa, Bharti \& Vashisht, Anubha. (2018). Magnitudes of Attractiveness in Employer Branding: Generation Z. International Journal of Applied Business and Economic Research. 15.

Veloutsou, C., Paton, A. and Lewis, J. (2005). Consultation and reliability of information sources pertaining the university selection: Some questions answered? International Journal of Educational Management, 19 (4), pp. 279-291. 